\title{
KAJIAN ARSITEKTUR FUTURISTIK PADA BANGUNAN PENDIDIKAN
}

\author{
Kartika Sahar*1, Wafirul Aqli ${ }^{2}$ \\ Program Studi Arsitektur, Universitas Muhammadiyah Jakarta ${ }^{1}$, \\ Program Studi Arsitektur, Universitas Muhammadiyah Jakarta ${ }^{2}$ \\ e-mail: ${ }^{* 1}$ kartikasahar14@gmail.com, ${ }^{2}$ wafirul.aqli@ftumj.ac.id
}

\begin{abstract}
Abstrak_ Arsitektur Futuristik merupakan gaya arsitektur yang berasal dari ide pemikiran atau gagasan ide yang mengungkapkan kebebasan dan berorientasi ke masa depan ke dalam bentuk yang tidak biasa, kreatif dan inovatif. Dari penelusuran literatur dan teori, telah dirumuskan beberapa prinsip Arsitektur Futuristik yaitu; (1) bangunan yang memiliki konsep masa depan; (2) bentuk bangunannya yang tidak biasa atau asimetris; dan (3) memanfaatkan kemajuan di era teknologi dalam penggunaan struktur dan konstruksi bangunannya. Penelitian ini mengambil studi kasus antara lain Jockey Club Innovation Tower di Hongkong, The Crystal of Knowledge UI di Depok, dan Universitas Multimedia Nusantara di Tangerang. Metode yang digunakan pada penelitian ini adalah metode menganalisis secara deskriptif-kualitatif tentang pengaplikasian ketiga prinsip arsitektur futuristik di ketiga studi kasus tersebut. Hasil dari penelitian ditemukan bahwa penerapan konsep masa depan dalam arsitektur futuristik akan sangat terlihat jika terdapat kekontrasan dari sekitarnya dalam hal bentuk dan tampilan bangunan. Semakin tidak biasa bentukan yang dipilih dan semakin asimetris juga menentukan seberapa maksimal prinsip futuristik itu diterapkan, dan penggunaan sistem struktur yang menggunakan teknologi terkini juga memperkuat penerapan prinsip tersebut.
\end{abstract}

Kata kunci: Arsitektur Futuristik; Arsitektur Pendidikan; Bangunan Pendidikan; Konsep Futuristik.

\begin{abstract}
Abstract_Futuristic Architecture is an architectural style derived from ideas or ideas that express freedom and future-oriented in an unusual, creative, and innovative form. From the search of literature and theory, several principles of futuristic architecture have been formulated, namely; (1) buildings that have a concept of the future; (2) unusual or asymmetrical shape of the building; and (3) utilizing advancements in the technological era in the use of building structures and construction. This research takes case studies including Jockey Club Innovation Tower in Hong Kong, The Crystal of Knowledge UI in Depok, and Multimedia Nusantara University in Tangerang. The method used in this study is a descriptive-qualitative method of analyzing the application of the three futuristic architectural principles in the three case studies. The results of the study found that the application of fut ure concepts in futuristic architecture will be very visible if there is a contrast from the surroundings in terms of the shape and appearance of the building. The more unusual formations chosen and the more asymmetric also determine how the maximum futuristic principle is applied, and the use of structural systems that use the latest technology also reinforces the application of these principles.
\end{abstract}

Keywords: Futuristic Architecture; Educational Architecture; Educational Buildings; Futuristic Concepts.

\footnotetext{
${ }^{1}$ Program Studi Arsitektur, Universitas Muhammadiyah Jakarta

2 Program Studi Arsitektur, Universitas Muhammadiyah Jakarta
} 


\section{PENDAHULUAN}

Futuristik merupakan paham yang mengungkapkan kebebasan untuk mengekspresikan ide atau gagasan ke bentuk yang tidak biasa, kreatif dan inovatif. Futuristik menghasilkan sesuatu yang dinamis, selalu berubah sesuai keinginan dan zamannya. Penerapan futuristik dapat dilihat pada tampaknya namun tetap memperhatikan dan memperhitungkan fungsi dari objeknya. (Diwarni \& Yardha, 2017).

Prinsip dasar dari arsitektur Futuristik mempunyai arti berorientasi ke masa depan dimana citra bangunannya memberikan kesan bahwa bangunan tersebut selalu mengikuti perkembangan zaman yang dapat dilihat dari bentuk atau citra bangunannya (Krisdianto, Purwantiasning, \& Aqli, n.d.). Bangunan memiliki bentuk yang tidak biasa atau tidak mengacu pada bentuk dasar geometris yang disebutkan pada buku Futurism: An Anthology bahwa futuristik membawa bentuk garis miring, lengkung atau elips (Diwarni \& Yardha, 2017) dan memanfaatkan kemajuan di era teknologi melalui penggunaan struktur yang modern (Krisdianto, Purwantiasning, \& Aq li, n.d.).

Menurut Haines (1950) dan Chiara dkk (1980) kriteria bangunan futuristik adalah "Bangunan dapat mengikuti dan mewadahi kegiatan yang akan selalu berkembang". Bangunan dituntut untuk dapat memberikan layanan kepada pengguna terhadap kegiatan yang akan terus berkembang dimana hal ini berarti harus memperhatikan kelengkapan yang mendukung proses kegiatan-kegiatan yang sedang berlangsung. Hal tersebut memungkinkan terjadinya penambahan atau pengurangan terhadap bangunan yang dalam prosesnya tidak mengganggu bangunan tersebut sehingga dalam proses perencanaan bangunan tersebut sudah dipikirkan secara matang. Serta Futuristik yang mengandung nilai-nilai bahwa futuristik itu dinamis, estetis, inovatif dalam segi teknologi yang dipakai dengan penerapan bentuk bebas yang tidak mengacu pada bentukbentuk tertentu. (Krisdianto, Purwantiasning, \& Aqli, n.d.).

Pendidikan memiliki arti sebuah proses pembelajaran, keterampilan dan kebiasaan suatu kelompok orang yang diwariskan dari generasi ke generasi melalui proses pengajaran, pelatihan dan penelitian dengan tujuan untuk mengembangkan potensi diri yang kedepannya akan bermanfaat untuk mewujudkan suatu tujuan yang akan membentuk masa depan. Salah satu faktor yang dapat meningkatkan kualitas pendidikan adalah faktor sarana fisik yang memadai untuk mewadahi kegiatan pengguna bangunan pendidikan tersebut, yaitu pengajar, murid, dan staf. Idealnya sebuah bangunan pendidikan adalah yang dapat mewadahi seluruh kegiatan pengguna bangunan tersebut, mulai dari fasilitas sarana dan prasarana sampai dengan 'citra' bangunan itu sendiri yaitu bangunan pendidikan sebagai tempat yang akan terus berkembang dan sebagai tempat terbentuknya masa depan tersebut (generasi-generasi penerus).

Pada bidang arsitektur, pendekatan arsitektur futuristik dan bangunan pendidikan memiliki kesamaan prinsip yaitu berorientasi ke masa depan atau sama-sama berkembang. Maka dari itu yang melatar belakangi penulis mengangkat penelitian ini adalah bagaimana penerapan arsitektur futuristik dapat menjadi faktor meningkatkan citra bangunan pada bangunan pendidikan tersebut. Contoh bangunan pendidikan yaitu The Jockey Club Innovation Tower di Hongkong merupakan kampus dengan jurusan terkait desain dimana bangunan ini menerapkan konsep futuristik bentuk fluid dan merupakan desain dari Arsitek Zaha Hadid yang sudah banyak menghasilkan karya bangunan dengan gaya futuristik. Lalu bangunan The Crystal of Knowledge atau Perpustakaan UI di Depok merupakan bangunan modern yang memiliki bentuk unik yaitu 
seperti bongkahan kristal dan mencolok dibandingkan dengan bangunan disekitarnya. Kemudian Universitas Multimedia Nusantara di Tangerang ini merupakan kampus yang mendapatkan penghargaan Energy Efficient Building dengan kategori Tropical Building dan memiliki konsep bangunan hemat energi bergaya futuristik dengan bentuk bangunannya seperti batu koral dan kepompong berwarna abu-abu. Maka dari itu, penelitian ini bertujuan untuk mengetahui penerapan gaya arsitektur futuristik pada bangunan The Jockey Club Innovation Tower, Perpustakaan UI dan Universitas Multimedia Nusantara. Adapun contoh penelitian penerapan arsitektur futuristik pada bangunan yang pernah dilakukan adalah dengan judul Prinsip Desain Arsitektur Neo Futuristik Pada Bangunan Komersial Karya Eero Saarinen yang meneliti penerapan prinsip yang digunakan yaitu gaya universal, less is more, nihilism dan kejujuran bahan pada bangunan-bangunan salah satu contohnya adalah meneliti dan menjabarkan kesan yang ditimbulkan dari bahan bangunan dan bentuk bangunan yang digunakan dengan tetap melihat acuan dari prinsip arsitektur neo futuristik itu sendiri misalnya bangunan tersebut mengekspos bahan material yang digunakan seperti rangka atap bangunan yang memiliki bentuk ikan paus dengan tujuan untuk melancarkan sirkulasi. Penelitian tersebut memberikan informasi kepada penulis dan kemudian akan mengadaptasi metode penelitiannya tentang cara menjabarkan penerapan prinsip pada objek bangunan yang diteliti.

\section{METODE}

Metode penelitian yang digunakan dalam penelitian ini adalah deskriptif-kualitatif. Metode pengumpulan data dilakukan dengan survey primer berupa observasi, studi pustaka, dan dokumentasi. Metode observasi dilakukan untuk mengetahui penerapan pendekatan futuristik pada bangunan pendidikan. Cara analisis dalam penelitian ini adalah dengan membandingkan penerapan pendekatan futuristik pada beberapa bangunan pendidikan yang ada dengan menganalisis penerapannya melalui prinsipnya. Adapun alat analisis itu sendiri adalah prinsip prinsip arsitektur futuristik yaitu; (1) penggunaan konsep masa depan yang dapat dilihat dari kekontrasan bangunan terhadap lingkungan disekitarnya seperti dari bentuk bangunannya yang berbeda sampai dengan fungsinya; (2) bentuk bangunan yang tidak biasa atau asimetris yang tidak berpegangan pada bentuk geometris; dan (3) pemanfaatan kemajuan di era teknologi dalam penggunaan struktur dan konstruksi bangunannya. Waktu penelitian yang dibutuhkan untuk meneliti bangunan yaitu pada tanggal 19 Agustus 2019 dengan observasi langsung ke bangunan The Jockey Club Innovation Tower, Perpustakaan UI dan Universitas Multimedia Nusantara.

\section{HASIL DAN PEMBAHASAN}

Hasil dan Pembahasan pada penelitian Kajian Arsitektur Futuristik pada Bangunan Pendidikan yaitu The Jockey Club Innovation Tower, Perpustakaan UI dan Universitas Multimedia Nusantara (UMN) memiliki fokus pada penerapan prinsip konsep masa depan (yang dapat ditunjukkan dari tidak terpaku pada bentuk kuno, less is more, ekspos bentuk dan kejujuran bahan), bentuk tidak biasa dan penggunaan struktur yang modern. 


\section{A. The Jockey Club Innovation Tower}

Bangunan The Jockey Club Innovation Tower yang dirancang oleh arsitek Zaha Hadid merupakan bangunan pendidikan dan penelitian terkait desain yang memiliki berbagai jurusan terkait desain, yaitu Product Design, Communication Design, Urban Design, Interaction Design, dan lain-lain. Bangunan ini termasuk ke dalam komplek bangunan The Hongkong Polytechnic University yang dahulunya merupakan bekas pabrik industri rumahan Hongkong, lalu pada tahun 2008 dilakukan renovasi besar-besaran untuk dijadikan pusat seni. Bangunan ini mulai dibangun pada tahun 2007, bangunan ini terdiri dari 15 lantai dan selesai dibangun pada pertengahan 2013. Menurut Zaha Hadid dalam situs The Hongkong Polytechnic University, bangunan ini memiliki gaya desain fluid pada lansekap, pelat lantai dan bagian lainnya menciptakan ruang publik baru yang dapar di gunakan untuk interaksi sosial.

Tabel 1. Penerapan Prinsip pada Bangunan The JCIT.

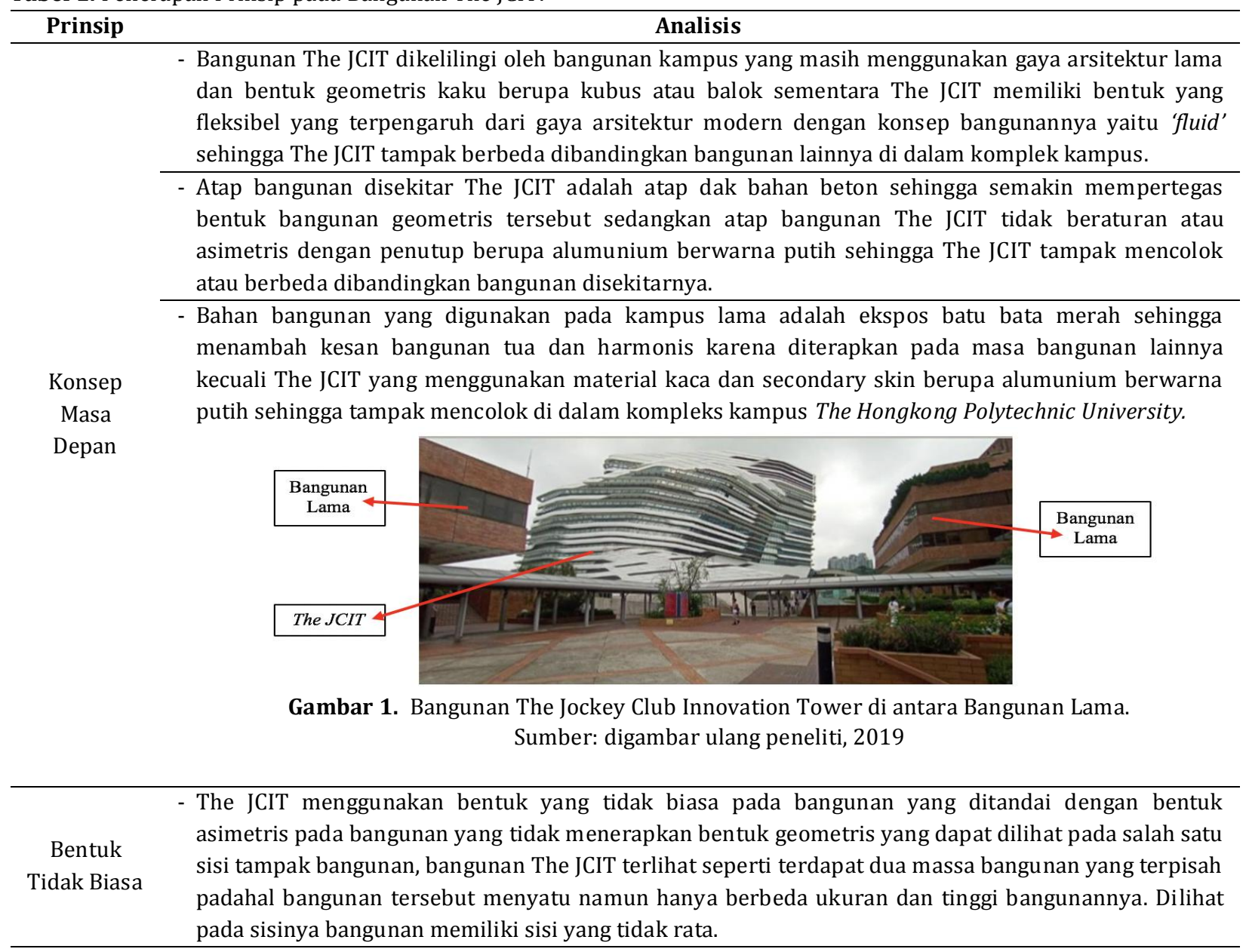






Gambar 2. Permukaan tidak Rata pada Tampak Timur The JCIT Sumber: digambar ulang peneliti, 2019

- Penerapan bentuk asimetris pada The JCIT ditemukan pada bagian tampak bangunan, blok plan, dan interior bangunan.

- Blok plan The JCIT dilihat dari berbagai sisinya tidak terpacu pada salah satu garis sumbu dan memiliki bentukan bangunan dilihat dari blok plan tidak beraturan. Jika pada bangunan yang menggunakan bentuk geometris biasanya terjadi pengulangan bentuk seperti 'mirror' pada bangunan sesuai garis sumbu namun pada bangunan The JCIT tidak terdapat pengulangan bentuk. Bentuk The JCIT pada bagian bawah lebih besar lalu semakin mengecil ke atas sehingga bertemu di ujung sehingga mengandung unsur sudut (tumpul) dan garis (lengkung) yang memberikan efek bangunan tidak kaku. Tidak hanya pada terpaku pada permainan visual namun The JCIT juga memperhatikan peletakkan massa dan penggabungan masa. Bangunan seperti dua masa yang kemudian menempel sehingga bangunan terlihat massive atau tunggal dan bentuk antara podium dan massa bangunan di atas podium berbeda.

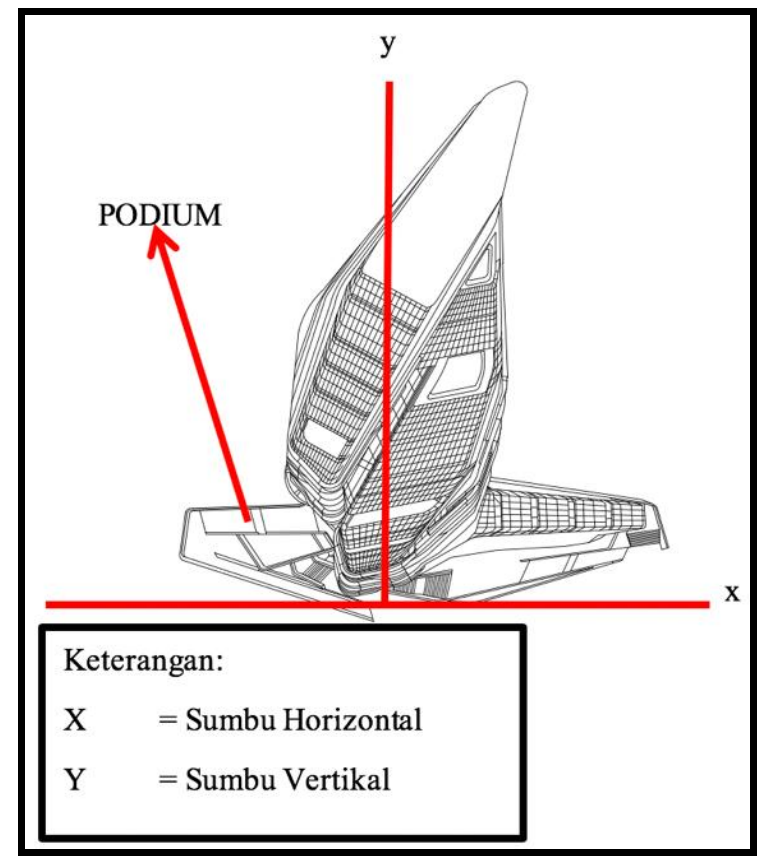

Gambar 3. Blok Plan The JCIT

Sumber: Digambar ulang Peneliti, 2019 
- Menggunakan konstruksi baja (sebagai struktur vertikal yang mendominasi) dan beton (pada lantai). Elemen struktural vertikal dan sistem lantai menggunakan konstruksi baja walaupun pada lantai menggunakan beton namun peletakannya di atas balok baja sehingga tetap sebagai struktur baja dan karena beton tidak bertindak sebagai struktur utama pada bangunan. Baja memiliki sifat kuat tarik, lebih lentur, ringan dan lebih kuat daripada aluminium maka dari itu baja dipilih sebagai kerangka bangunan dibandingkan alumunium yang digunakan untuk fasad bangunan. Bangunan pada masa modern memiliki bentuk yang tidak biasa maka dari itu kemajuan teknologi dapat dimanfaatkan dimana baja yang dilihat dari sifat bahanya dapat mengikuti bentuk bangunan yang tidak biasa.

Pemanfaata

n Kemajuan

di Era

Teknlogi pada

Struktur

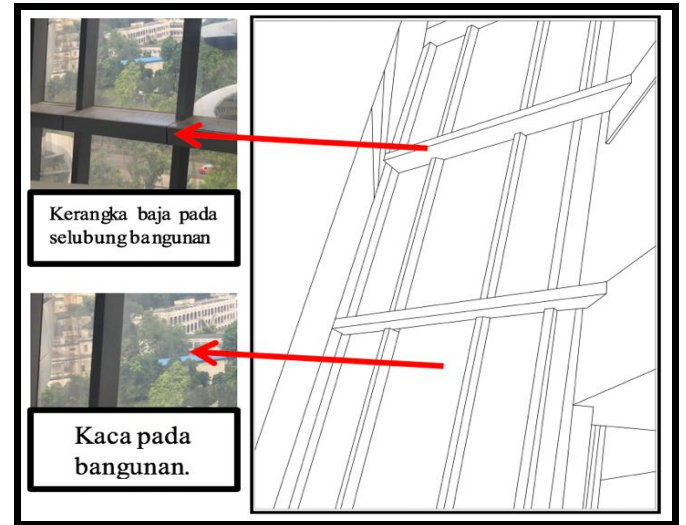

Gambar 4. Struktur pada The JCIT

Sumber: Digambar Ulang Peneliti, 2019

- Selubung bangunan menggunakan secondary skin dari bahan alumunium yang dapat dipasang dengan cepat dan ringan pada bangunan dan dapat menyesuaikan dengan lengkungan pada permukaan bangunan.

Kesimpulannya bangunan The JCIT sudah memanfaatkan kemajuan teknologi pada hal struktur dan konstruksi bangunan seperti mengganti bahan struktur dengan yang cepat dalam pemasangan karena bahan sudah dibuat atau custom dan menggunakan material yang dapat mengikuti bentuk bangunannya, namun masih kurang praktis karena penggunaan beton yang cukup banyak dijumpai pada bangunan yang perlu dikerjakan langsung ditempat contohnya pengecoran beton dan bukan hanya sekedar langsung kepada proses pemasangan.

\section{B. The Crystal of Knowledge UI (Perpustakaan UI)}

Perpustakaan UI merupakan pengembangan dari perpustakaan pusat yang dirancang oleh DCM Architect lebih tepatnya oleh arsitek Budiman Hendropurnomo merupakan bangunan dengan fungsi sebagai perpustakaan dengan banyak fasilitas didalamnya. Bangunan ini termasuk ke dalam komplek bangunan Kampus UI dan Perpustakaan UI memiliki lahan seluas 3 hektar dengan 8 lantai. Bangunan ini memiliki konsep sustainable building yang ecofriendly. Bangunan ini menghadirkan model bangunan masa depan dan menekan jumlah penggunaan energi.

Tabel 2. Penerapan Prinsip pada Bangunan Perpustakaan UI.

\begin{tabular}{|c|c|}
\hline Prinsip & Analisis \\
\hline \multirow[b]{2}{*}{$\begin{array}{c}\text { Konsep Masa } \\
\text { Depan }\end{array}$} & $\begin{array}{l}\text { - Bangunan Perpustakaan UI dikelilingi oleh bangunan kampus lama sehingga masih memiliki } \\
\text { gaya bangunan lama dengan bentuk geometris persegi sementara Perpustakaan UI memiliki } \\
\text { bentuk yang asimetris. }\end{array}$ \\
\hline & $\begin{array}{l}\text { - Atap bangunan kampus lama disekitar Perpustakaan UI menggunakan atap biasa berupa pelana } \\
\text { dan limasan dengan penutup genteng merah dan Perpustakaan UI memiliki bentuk atap } \\
\text { lingkaran dilihat dari blok plannya, namun terdapat beberapa bangunan yang memiliki bentuk } \\
\text { atap lingkaran sehingga bukan bangunan Perpustakaan UI saja yang menggunakan bentuk dasar } \\
\text { lingkaran yang membedakannya adalah bahan dan fungsi penutup atapnya, dimana }\end{array}$ \\
\hline
\end{tabular}




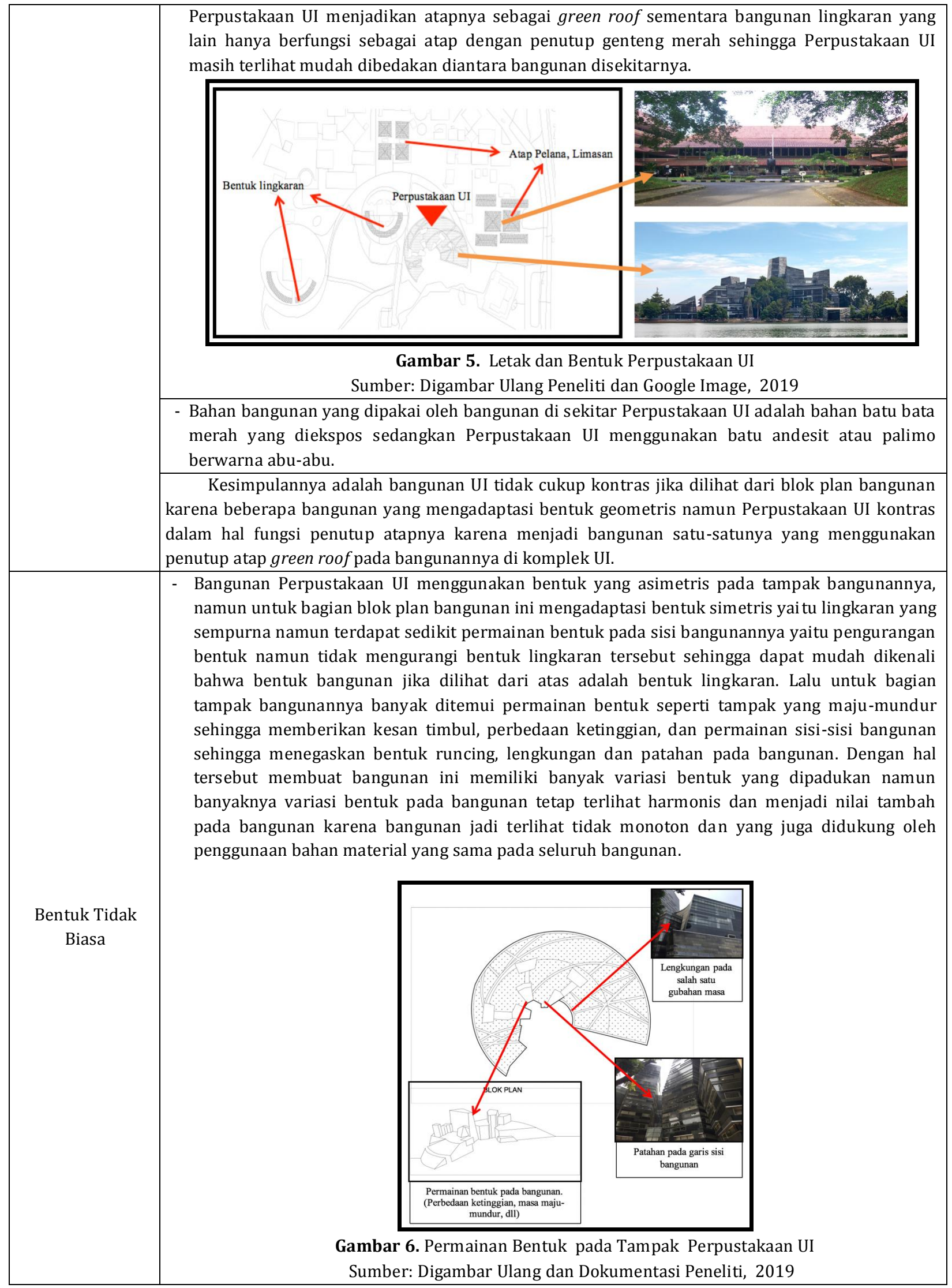




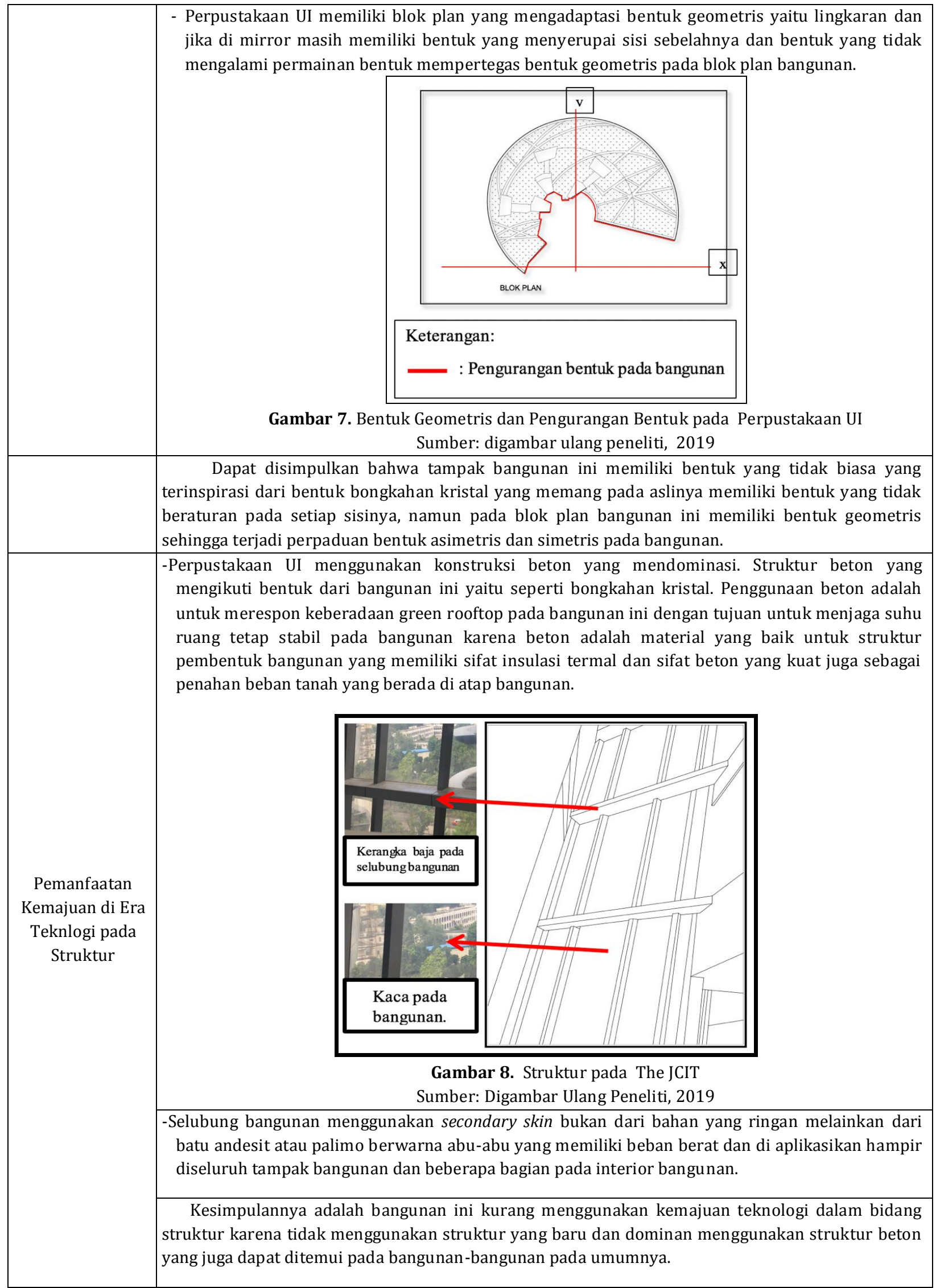




\section{Universitas Multimedia Nusantara (UMN)}

Universitas Multimedia Nusantara dibangun dan dirancang oleh PT Multimedia Land selaku kontraktor dan arsitek Budiman Hendropurnomo dengan fungsi bangunan adalah bangunan pendidikan atau kampus yang memiliki berbagai macam jurusan. Bangunan ini merupakan proyek lanjutan dari bangunan hemat energi sebelumnya dan beroperasi dan pengembangan pembangunan dari tahun 2005 sampai 2017 dan rencana untuk sampai di tahun 2030. Bangunan ini memiliki bentuk seperti cangkang telur atau kepompong dengan konsep bangunan hemat energi dengan menyisakan 40 persen area hijau kampus yang bertujuan untuk melakukan efisiensi energi.

Tabel 3. Penerapan Prinsip pada Bangunan UMN.

\begin{tabular}{|c|c|}
\hline Prinsip & Analisis \\
\hline \multirow{6}{*}{$\begin{array}{c}\text { Konsep Masa } \\
\text { Depan }\end{array}$} & $\begin{array}{l}\text { - Bangunan UMN terletak di antara permukiman perumahan yang memiliki bentuk seragam } \\
\text { dengan bentuk bangunan UMN yang cukup tinggi yaitu } 13 \text { sampai } 18 \text { lantai dan besar sehingga } \\
\text { bangunan UMN mudah dikenali dan tampak mencolok di antara pemukiman tersebut yang juga } \\
\text { dilihat dari fungsi bangunannya yaitu bangunan fungsi pendidikan di antara pemukiman warga. } \\
\text { Namun untuk konsep bangunan futuristik UMN bukan yang menjadi satu-satunya bangunan } \\
\text { futuristik melainkan terdapat satu bangunan juga yang menerapkan konsep futuristik yaitu JHL } \\
\text { Solitaire sehingga UMN tidak cukup mencolok pada konsep bangunan di sekitar lingkungan } \\
\text { tersebut. }\end{array}$ \\
\hline & \\
\hline & $\begin{array}{l}\text { Keterangan: } \\
=\text { Perumahan } \\
\end{array}$ \\
\hline & $\begin{array}{c}\text { Gambar 9. Letak Bangunan UMN } \\
\text { Sumber: digambar ulang peneliti, } 2019\end{array}$ \\
\hline & $\begin{array}{l}\text { - Atap bangunan di sekitar UMN adalah bentuk lengkung dengan penutupnya adalah bahan } \\
\text { alumunium yang berlubang dan dapat mengikuti bentuk bangunan sementara di lingkungan } \\
\text { sekitarnya yaitu perumahan menggunakan atap biasa berupa pelana dan limasan dengan } \\
\text { penutup bahan genteng keramik. }\end{array}$ \\
\hline & $\begin{array}{l}\text { - Berada di lingkungan perumahan yang seragam menggunakan bahan batu bata yang sudah } \\
\text { dilapisi lapisan dinding sehingga membuat UMN tampak mencolok karena UMN menggunakan } \\
\text { bahan alumunium yang berlubang-lubang berdiameter kecil dan menyelubungi bangunan secara } \\
\text { keseluruhan dan hampir tidak memiliki bukaan berupa kaca pada tampaknya sementara } \\
\text { bangunan lainnya selain perumahan banyak yang menggunakan kaca pada tampak } \\
\text { bangunannya. }\end{array}$ \\
\hline
\end{tabular}














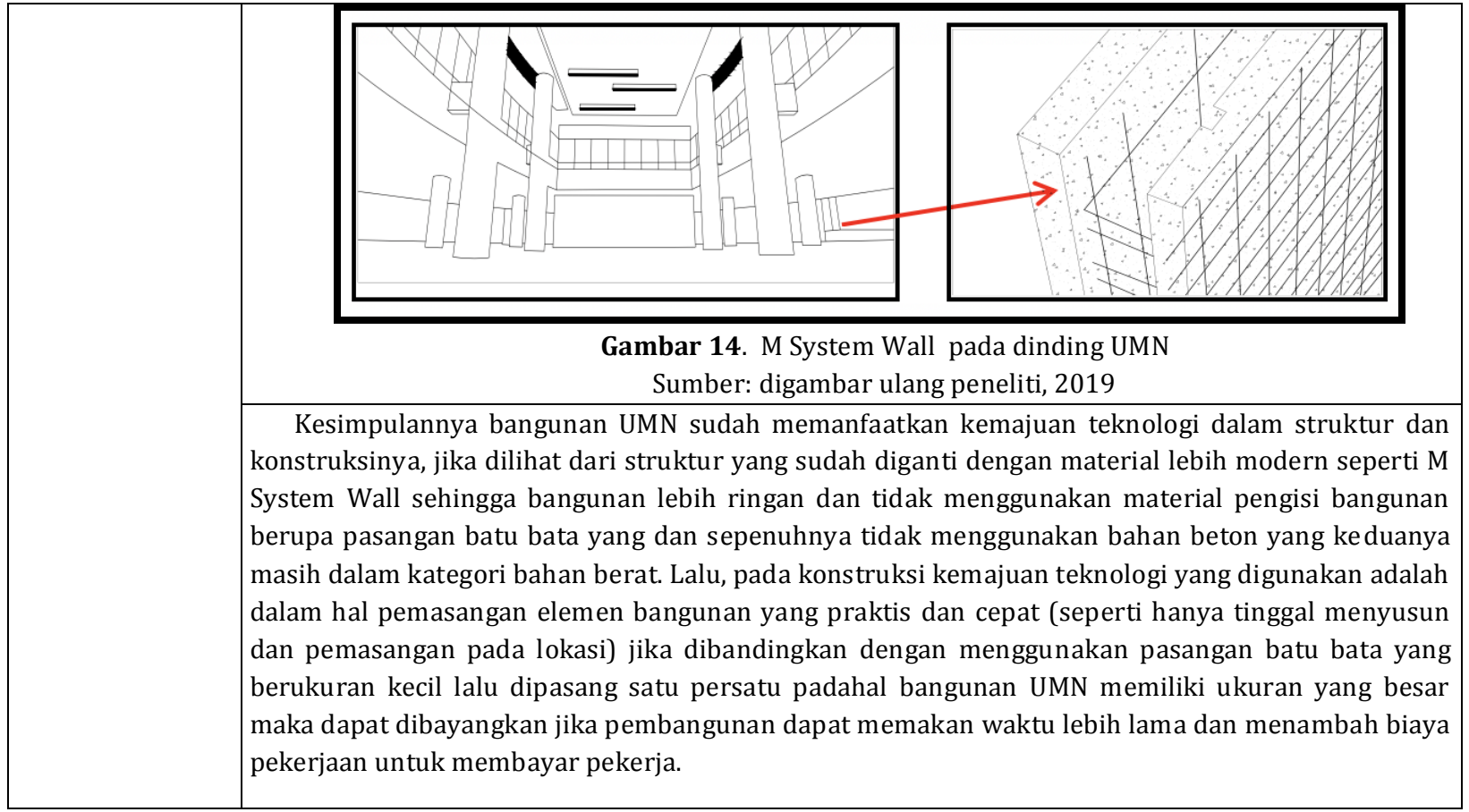

Sumber: Hasil Analisis, 2019

Berikut ini analisis prinsip dari ketiga bangunan yaitu bangunan The JCIT, Perpustakaan UI, dan UMN.

Tabel 4. Analisis Prinsip

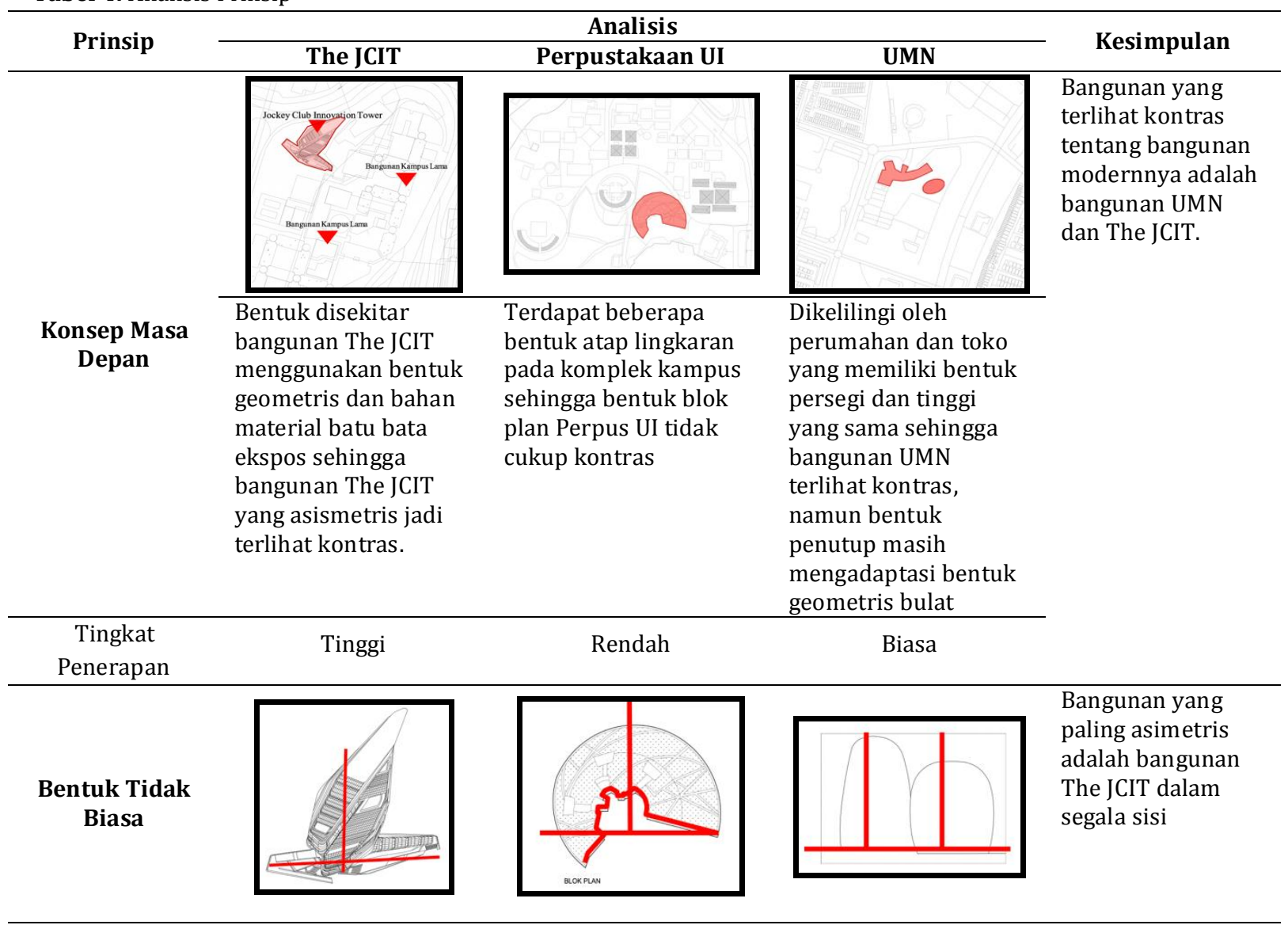




\begin{tabular}{|c|c|c|c|c|}
\hline & $\begin{array}{l}\text { Bangunan The JCIT } \\
\text { dalam segi bentuk } \\
\text { gubahan massa dan } \\
\text { tampak tidak } \\
\text { mengadopsi bentuk } \\
\text { geometris begitupun } \\
\text { jika dilihat pada } \\
\text { sumbu x,y bangunan } \\
\text { tetap asimetris dari } \\
\text { segala sisi }\end{array}$ & $\begin{array}{l}\text { Perpustakaan UI tidak } \\
\text { mengadopsi bentuk } \\
\text { geometris pada } \\
\text { gubahan massa yaitu } \\
\text { bentuk kristal namun } \\
\text { pada blok plan masih } \\
\text { mengadopsi bentuk } \\
\text { geometris bulat dengan } \\
\text { terdapat pengurangan } \\
\text { bentuk. }\end{array}$ & $\begin{array}{l}\text { Bangunan UMN masih } \\
\text { mengadopsi bentuk } \\
\text { geometris bulat } \\
\text { begitupun dalam } \\
\text { tampak bangunannya } \\
\text { yang jika di miror } \\
\text { masih serupa dengan } \\
\text { bentuk sisi yang di } \\
\text { mirror. }\end{array}$ & \\
\hline $\begin{array}{c}\text { Tingkat } \\
\text { Penerapan }\end{array}$ & Tinggi & Biasa & Rendah & \\
\hline \multirow[t]{2}{*}{$\begin{array}{l}\text { Kemajuan di } \\
\text { Era Teknologi } \\
\text { pada Struktur }\end{array}$} & & Btite & & \multirow{3}{*}{$\begin{array}{l}\text { Bangunan yang } \\
\text { lebih praktis dalam } \\
\text { hal pembangunan } \\
\text { adalah bangunan } \\
\text { UMN karena } \\
\text { material utama } \\
\text { yang digunakan } \\
\text { sudah dicustom } \\
\text { dan lebih } \\
\text { terkonsentrasi } \\
\text { dalam hal } \\
\text { pemasangan pada } \\
\text { saat dilokasi dan } \\
\text { material yang } \\
\text { digunakan juga } \\
\text { lebih merespon } \\
\text { untuk bangunan } \\
\text { dengan konsep } \\
\text { hemat energi. }\end{array}$} \\
\hline & $\begin{array}{l}\text { Bangunan The JCIT } \\
\text { menggunakan } \\
\text { material beton pada } \\
\text { podium dan lantai } \\
\text { dengan proses } \\
\text { pengecoran, baja } \\
\text { untuk rangka } \\
\text { bangunan yang sudah } \\
\text { custom dan pasang } \\
\text { melalui proses } \\
\text { pengelasan, kaca } \\
\text { untuk tampak } \\
\text { bangunan yang sesuai } \\
\text { custom dan dilokasi } \\
\text { hanya proses } \\
\text { pemasangan dan } \\
\text { aluminium untuk } \\
\text { secondary skin } \\
\text { mengelilingi } \\
\text { bangunan yang sudah } \\
\text { dicustom dan dilokasi } \\
\text { dengan proses } \\
\text { pengelasan, dan lain- } \\
\text { lain namun dari segala } \\
\text { material dan cara } \\
\text { pengerjaan tetap } \\
\text { dapat mengikuti } \\
\text { bentuk bangunan. }\end{array}$ & $\begin{array}{l}\text { Perpustakaan UI } \\
\text { menggunakan beton } \\
\text { sebagai struktur utama } \\
\text { dan batu-batu } \\
\text { bertekstur licin pada } \\
\text { tampak dan material } \\
\text { tersebut dapat } \\
\text { menambah beban } \\
\text { bangunan karena pada } \\
\text { dasarnya kedua } \\
\text { material tersebut sudah } \\
\text { berat. Proses } \\
\text { konstruksi bangunan } \\
\text { dengan beton adalah } \\
\text { dicor di tempat } \\
\text { sementara batu andesit } \\
\text { sudah siap pasang } \\
\text { karena sudah di custom } \\
\text { sesuai keinginan yang } \\
\text { dapat dilihat dari } \\
\text { ukuran ukurannya yang } \\
\text { sama pada tampak. }\end{array}$ & $\begin{array}{l}\text { Bangunan UMN } \\
\text { menggunakan } \\
\text { struktur modern } \\
\text { seperti bahan } \\
\text { prefabrikasi yaitu } \\
\text { panel aluminium } \\
\text { perforated yang dapat } \\
\text { membantu sirkulasi } \\
\text { udara dan panas pada } \\
\text { bangunan dan M } \\
\text { System Wall pengganti } \\
\text { batu bata yang ringan } \\
\text { dimana keduanya } \\
\text { dapat mengikuti } \\
\text { bentuk bangunan dan } \\
\text { dalam proses } \\
\text { konstruksi lebih cepat } \\
\text { karena di lokasi bisa } \\
\text { langsung ke tahap } \\
\text { pemasangan. }\end{array}$ & \\
\hline $\begin{array}{c}\text { Tingkat } \\
\text { Penerapan }\end{array}$ & Biasa & Rendah & Tinggi & \\
\hline
\end{tabular}

Sumber: Hasil Analisis, 2019

Berdasarkan analisis yang dilakukan pada ketiga bangunan tersebut penerapan arsitektur futuristik ke dalam bangunan yaitu berdasarkan prinsip-prinsipnya adalah bangunan dapat didesain dengan memperhatikan bangunan di sekitarnya mulai dari bentuk sampai ke konsep bangunannya untuk mendukung prinsip futuristik yaitu bangunan yang akan direncanakan tidak tampak sama dan gaya arsitektur futuristik tersebut lebih menonjol dibandingkan bangunan disekitarnya, selanjutnya penerapan bentuk yang asimetris atau unik dan tidak menggunakan arsitektur tradisional ke bangunan mulai dari eksterior sampai interiornya yang dapat meningkatkan kesan modern atau futuristik bangunan yang didukung oleh penggunaan struktur 
dan konstruksi bangunan yang modern dalam artian struktur yang dapat mengikuti bentuk bangunan tersebut, lalu pengerjaan yang mudah, cepat dan efisien, selain itu juga memperhatikan lingkungan sekitar dan memanfaatkannya contohnya bangunan yang dapat menghemat energi melalui bahan material bangunan, memaksimalkan fungsi secondary skin yang memiliki unik dan sehingga selain merancang bangunan yang baik dalam berbagai segi juga dapat menambah kesan modern atau maju pada bangunan tersebut.

\section{KESIMPULAN}

Arsitektur Futuristik yang diterapkan pada bangunan pendidikan yang diteliti, terdapat bangunan yang paling banyak dalam menerapkan prinsip gaya futuristik yaitu bangunan The Jockey Club Innovation Tower. Penerapan gaya arsitektur futuristik pada bangunan ini antara lain dapat dilihat dari letak bangunan yang berada di komplek PolyU Design Campus Hongkong, dimana bangunan pada kompleks kampus tersebut adalah bangunan tua yang berbentuk geometris dan memberikan kesan tua sedangkan bangunan The Jockey Club Innovation Tower memiliki konsep modern dengan bentuk yang non-geometris yang tidak terpaku pada gaya desain masa lalu dan dalam penggunaan struktur dan konstruksi yang canggih sehingga bangunan ini kontras dibandingkan dengan bangunan disekitarnya. Sedangkan dua studi kasus lainnya yaitu bangunan UMN dan Perpustakaan UI tidak dominan dalam menerapkan prinsip futuristik, salah satu contohnya adalah pada bentuk bangunan yang masih mengadaptasi bentuk dasar geometris, dan prinsip lainnya yang tidak terlalu mencolok sehingga pada terlihat tidak cukup kontras terhadap lingkungan disekitarnya dan tidak seluruhnya atau tidak dominan dalam penerapan gaya futuristik pada bangunannya.

\section{DAFTAR REFERENSI}

Aaron, B. (1998). Zaha Hadid: The Complete Buildings and Project.

Abuyahman, R. F. (n.d.). Pengembangan Fasilitas Universitas Panca Bhakti Pontianak. 3 (September 2015), 140155.

Aritonang, L., \& Chandra, W. (2016). Aplikasi Penataan Ruang dengan Gaya Desain Futuristik Pada Cyber Café Sebagai Pengembangan Bisnis Cyber Game Café Di Medan. Jurnal Sains Dan Teknologi ISTP, 06(01), 22-28. https://doi.org/2356-0878

Asim, F., \& Shree, V. (2018). A Century of Futurist Architecture: From Theory to Reality. Krishi Sanskriti Publications, (December). https://doi.org/10.20944/preprints201812.0322.v1

Diwarni, S., \& Yardha, M. S. (2017). Prinsip Desain Arsitektur Neo Futuristik Pada Bangunan Komersial Karya Eero Saarinen. JAUR: Journal of Architecture and Urbanism Research, 1(1), 27-36.

Hatmoko, A., Wulandari, W., Alhamdani, M. R., \& Leonard, M. L. (2016). Arsitektur Bangunan Pendidikan.

Inez, E. (2014). Penerapan Prinsip Arsitektur Modern Pada Bangunan Fakultas Pendidikan MIPA. (78). Retrieved from

https://www.academia.edu/33797853/Penerapan_Prinsip_Arsitektur_Modern_Pada_Bangunan_Fpmipa_Up i_Bandung

Krisdianto, A., Purwantiasning, A. W., \& Aqli, W. (n.d.). Penerapan Arsitektur Futuristik Terhadap Bangunan Gundam Base Indonesia Di Jakarta. 1-8.

L., \& Alhamdani, M. R. (2014). Penerapan Material Kaca dalam Arsitektur. Langkau Betang: Jurnal Arsitektur, 1(2), 30-42. https://doi.org/10.26418/lantang.v1i2.18798

Lawrence Rainey, Christine Poggi, L. W. (n.d.). Futurism: An Anthology.

Megasari, R. (2014). Peningkatan Pengelolaan Sarana dan Prasarana Pendidikan Untuk Meningkatan Kualitas 
Pembelajaran di SMPN 5 Bukittinggi. Administrasi Pendidikan, Vol. 2, pp. 1-13.

Nur'aini, R. D. (2017). Analisis Konsep Green Roof Pada Kampus School of Art, Design and Media Ntu Singapore Dan Perpustakaan Ui Depok. NALARs, 16(2), 161. https://doi.org/10.24853/nalars.16.2.161-168

Parmo, P., Sucipto, M. H., \& Sumarkan, S. (2016). Penilaian Kondisi Bangunan Gedung Sekolah Dasar Negeri Studi Kasus di Sekolah Dasar Negeri Se-Kabupaten Madiun. EMARA: Indonesian Journal of Architecture, $2(1), 42$. https://doi.org/10.29080/emara.v2i1.17

Prakoso, N. A., Lamahala, A. K., \& Sentanu, G. (2014). Kajian Penerapan Material pada Selubung Bangunan yang Mempengaruhi Kenyamanan Termal dan Visual. Reka Karsa, 2(2), 1-12. https://doi.org/10.26760/REKAKARSA.V2I2.462

Ruly, P. (2014). Struktur Beton Bertulang dalam Perspektif Fleksibilitas Bentuk dan Arsitektur Plastis pada Rancangan Dekonstruksi. Forum Bangunan, 12. https://doi.org/10.1016/j.cell.2009.01.043

Wahyuning, T. E., Wahyu, W. A. K., \& Widi, S. (2015). Aplikasi Karakteristik Arsitektur Futuristik pada Terminal Penumpang Pelabuhan Yos Sudarso di Kota Ambon. 02. 